\title{
Male offenders disclaiming accountability: A gender perspective on texts about domestic violence from two centuries
}

\author{
Gunilla Byrman \& Ulf Drugge
}

\section{Introduction}

This article compares cross-examination reports from nineteenth-century fatal domestic violence cases with interviews from contemporary cases of domestic violence. In these cases men who were closely related to women in both old and contemporary cases used violence against women, which is "violence directed towards women because they are women" (Hearn et al. 2016). The narrative of statements of the parties in these cases will be examined taking into account the various texts' social and discursive practices in a comparative gender perspective. There are more than 150 years between the oldest and the contemporary texts in the studied material, and during that time society and the legislation have changed, and the relationship between men and women has become more equal through time.

Gender and domestic violence are often closely linked. In a majority of all these cases the violence begins in the unequal power relationship between men and women. What happens or does not happen after the assault and how society handles social problems is of crucial importance here.

\section{Background}

Swedish nineteenth-century society was considerably different from the post-modern, urbanized and highly technologically developed Sweden of today. For instance, about ninety per cent of the Swedish population was then living and working in agriculture (Carlsson 1994:28-29). Today fifteen per cent live in the Swedish countryside and only about two per cent are nowadays occupied in the agricultural sector (Statistisk årsbok 2014:88 \& 265).

Laws utilized in the older cases derived initially from the year 1734, when the Misdeed Code (Missgärningsbalken) was introduced and became a conservative force in trying crimes in accordance with old Lutheran views combined with Mosaic elements from the Old Testament. At the same time this code was shaped in a clear, plain legal form, which contributed to minimizing arbitrary interpretations (Anners 1983:84; Inger 1997:132).

The nineteenth-century legal process meant that the county sheriff started the judicial inquiry and put the suspects in custody. Then the sheriff reported the crime to the county governor's secretariat and the district judge's commission prepared the trial. If necessary an autopsy was performed, with a forensic medical report. It should be pointed out that the cases selected from the nineteenth century are all domestic violence with fatal consequences. If these cases were not suspected murder cases they would mostly not have been recorded at all, since a husband was entitled to beat his wife, children, and servants at least as much as was 
needed to keep order in the household. Moreover, domestic violence was not subject to public prosecution in older times.

The legal process related to contemporary cases can be described as follows. When a crime is committed this can become known to the police through the victim or through someone else who reports the crime. The police have an obligation to prepare an investigative report on the spot and as soon as possible if it is suspected that a crime has been committed. The investigation has two purposes: to investigate who may be suspected of the crime, and to assess whether there is sufficient evidence to prosecute (cf. Haworth 2013:173-176). Those who have been victims of the crime can have a support person and courtroom counsel, who helps the victim before, during and after the trial. In a similar way, the suspect also is entitled to a public defender. In the investigation, the suspect, the victim and witnesses are interviewed before the court trial, and the interviews can be audiotaped or videotaped, but they have to be documented in a written record that can be handed over to the prosecutor. The writer, often a police officer, has to decide what to put in the written interview and what to leave out, all non-verbal features, the investigator's questions, discourse markers and interruptions that can be significant for the interpretation of a statement (Coulthard 1996:170171). Most of the time things that happen during the interview are not documented in the text. The interview should be read aloud to or read by the interviewee for approval. Sometimes the text is only in draft form when approved by the interviewee, as appears quite often in the data examined in this study. If necessary and for the clarity of the investigation, the police might also ask for opinions from experts such as social workers or forensic doctors.

If a person is detained, the suspect's social contacts might be restricted due to a decision by the prosecutor. Common measures to secure evidence include recording interrogations on video, documenting the victim's injuries and gathering forensic medical reports. The police can also seize clothing, weapons and other artefacts as evidence. The victim's own documentation, social media, diary entries, text and film can also be used to support the story.

The police have legal rights to detain a suspected person while awaiting a prosecutor's decision. The prosecutor can request that a person be held in custody if there is reasonable suspicion of a crime that can render a minimum of one year in prison, and if there is a risk of absconding; if no charge is made, the police are not allowed to keep the suspect more than 14 days. There is no limit to how long a person can be detained, which Sweden has been criticized for by the EU and the UN (Delling 2014).

The texts are important in an investigation, and it is in the police's best interest to get these texts right and judicially tenable (cf. Rock 2013:78-80). Ultimately, this study touches on matters of importance for the personal security and equality of all citizens in legal rights, and in cases of domestic violence it is also a serious problem for many women who live in apparently dependent relationships with violent men (Brottsförebyggande rådet 2009:24-34).

Domestic violence is a social problem in Swedish society, not only in the nineteenth (cf. Lindstedt Cronberg 2005:23) but also in the twenty-first century (Lundgren et al. 2001), and the language is often an issue. If the language in the investigations was handled with care and awareness it would perhaps be possible for Swedish prosecutors to be successful in bringing more cases of domestic violence to court than what is common today (Byrman 2014:260).

Below the aim and research questions and design of the study will be presented through an account of the material, method and theory. The results will be reported through illustrative 
examples from the material, and by a presentation of the structure of the texts. In the examination of the content and the language, the focus is on how the suspects verbally defend their actions against the women and how the written texts construct this during cross-examination with the suspected men in the old days and in interviews nowadays. Obvious continuities and changes will be discussed by comparing old and modern texts and seeing how the violence could be understood. In a conclusion we address conditions and consequences in terms of power related to the gender system and to the legal context in the nineteenth century and in the present day.

\section{Aim and research questions}

The aim is to study how the words and the actions of the parties are presented in written reports and how we understand the cases and the violence, and what the cases convey about the society in which the texts were produced, i.e. what roles the texts play in the legal process of the nineteenth century and in the twenty-first viewed in a comparative gender perspective. We address the following research questions:

- How does the suspect speak about the crime he is suspected of?

- How can the suspect's words be understood in a gender perspective?

The structure, language and content are examined in written records of suspects' verbal defences of their criminal offences against women with whom they have a close relationship, but also what the texts contain and how the texts are structured on a macro level, i.e. what evidence emerges and how it corresponds to the constituent elements of the offence and how the suspect speaks of the crime and how his evidence is written in the texts. If the texts have a transparent macro structure it can make them easier to read and understand.

\section{Material - four investigations of domestic violence past and present}

For this study four court cases were strategically selected, that is, selected in order to represent crucial social factors such as the age of individuals involved and the social settings and circumstances commonly occurring in cases of men's violence against women. These cases originate from two much bigger corpora of texts about criminal investigations from written records from the nineteenth century of cross-examinations in court and from twenty-firstcentury interviews in police investigations.

The two old cases are from 1836 and 1851 and contain 26,014 words, and the cases are sampled from court records (Sw. domböcker). The cases have the offence of murder or manslaughter, which is the fatal result of years of repeated domestic violence (cf. Ferguson 2010: 209-217, 244-245), and consist of two, then middle-aged couples, both living in rural settings:

- From 1836: Anders (male, 46 years) and Brita Stina (female, 42 years)

- From 1851: Lars Erik (male, 40 years) and Johanna (female, 31 years) 
Briefly, the material from the nineteenth century contains interviews with suspects, witnesses and written certifications from officials such as doctors and vicars. The victim of the offence is dead and therefore cannot testify.

The contemporary cases are all from 2007. They contain 8,956 words and involve one middle-aged couple and one young couple, both in urban settings:

- From 2007: Enoch (male, 61 years) and Erna (female, 66 years). The offence is gross violation of a woman's integrity or assault.

- From 2007: Besin (male, 24 years) and Bahiri (female, 24 years). The offence is gross violation of a woman's integrity.

The two cases from 2007 contain interviews with plaintiffs, suspects, witnesses, and police memoranda, written certificates from officials such as doctors and social workers. The texts old and contemporary - contain altogether 34,970 words.

\section{The documentation of the interviews in the legal process past and present}

In this section the circumstances of the writing situation in the legal process will be described. Interviews are crucial in an investigation in both past and present times. All the cases discussed are under public prosecution. Interviews with the plaintiff, suspects and witnesses are conducted in court; they are intended for the public prosecutor and the statements are documented in reported written interviews. The written documentation is not only a communicative tool in the judicial process, but also a mirror of contemporary society's view of men's violence against women and thus becomes a social construction that is surrounded by specific attributes (cf. Gumbel 2000:31).

In the old cases the cross-examinations took place during the trial. The old texts can be described as summaries of what took place during and after the trial, documented with quill and ink.

In the contemporary reports all possible technical equipment is available, but it is not always used because it takes time to analyse the data. Therefore, it is routine that contemporary reports are typed into a computer during the interview. The modern written interviews are a part of the investigation, and the interview reports then become part of the larger investigation report, as important material for public prosecutors because they form a vital basis for the decision whether to drop the case or take it to court (Komter 2013:141-143). During trial, suspects, plaintiffs and witnesses will normally be re-asked questions that they have already replied to during the investigation preceding the trial in the court.

For both the old and the contemporary documents we cannot be sure about what was documented by the scribe in court or by the police officer and what was left out, which is a problem in the judicial process. For the contemporary texts, however, there might sometimes, but not always, be audiotapes or videotapes with documentation of the interviews as well. 


\section{Analytical framework: Comparative analysis, critical discourse analysis and gender theory}

In this article we utilize comparative analyses that compare and contrast phenomena as two nineteenth-century legal cases are compared with two cases from the beginning of the twenty-first century. The two pairs of cases contain similar domestic crimes, men's violence against women in the home. The violence is in all cases repeatedly committed during a period of time between two parties who know each other well as spouses or as girlfriends and boyfriends. The various legal processes have both similarities and contrasting elements, including social and discursive practices, but although there are large contextual, social, economic and cultural differences between the old and the modern cases, comparative analyses aim at revealing both continuities and changes (cf. Macfarlane 2004).

The method used involves close reading of the four cases. Both the legal contexts and inequalities between women and men will be observed as well as the words and actions of the parties and what the cases convey about the society in which the texts were produced. The focus is on the narratives of the suspects and their description of their involvement in the crime (cf. Komter 2002:168-192; Komter 2006:201-228; Komter 2013).

To fulfil the aim and to answer the research questions we will use critical discourse analysis (CDA) to give a model for explaining what is detected in the analysis. CDA is a framework containing and implying social identities, power relations, knowledge and value systems that are established and maintained by discursive practices (Fairclough 2010:1-21). The theoretical framework is a dialectic approach to discourse, using methods from discourse analysis, and rhetoric with the focus on linguistic features. Particular attention is paid to the rhetoric and the narrative of the suspects in the texts (cf. Komter 2002).

Tina Mattsson (2013) has done research on domestic violence, and her research highlights how the work of such a unit takes place in a field of violence, power and gender where it is difficult to make visible violence and women's vulnerability (Mattsson 2013:150). In Mattsson's view research on violence based on different perspectives is divided on the issue of how violence is understood. Although the majority of research has feminist perspectives as a starting point, there is a dividing line between perspectives that are based on a structural comprehension (Eckert \& McConnell-Ginet 2013:34) and perspectives based on a more relational understanding (cf. Hydén 1995a, 1995b). The relational approach places less emphasis on power relations and is interested instead in violence as the result of conflict between the two parties. The relational understanding highlights the violence enacted between women and men, rather than as exercised by men against women (Mattsson 2013:151-152).

A violent relationship alternates between violence and warmth, which creates the women's emotional dependence on the man. In combination with being insolated with the man, the line between what is good and evil is dissolved for the woman. Hydén (1995a, 1995b) is interested in how women and men have a shared interpretation of the violence created. Hydén states that violence tends to be generated from an argument. In the quarrel, the woman has the opportunity for initiative and action, but when it turns into violence, she becomes limited and a victim of the man's physical power. After the violence both often agree that the violence was a morally dubious act. The woman then assumes a position of power, because she has reasons to leave the relationship. If she chooses to stay the couple creates a common story of 
violence that tones down the violent elements. The woman can then also take on the responsibility for the violence, for example by citing her nagging as a reason for the man's lack of control (cf. Hydén 1995a, 1995b).

Eckert \& McConnell-Ginet's gender theory is applied (2013), where the gender system is assumed to have two basic logics: dichotomy, the taboo of keeping apart, i.e. the female and the male should not be mixed; and hierarchy, the fact that it is the man who is the norm. Why does the world look like this? Eckert \& McConnell-Ginet explain it by saying that a general oppression must have a general and structural explanation. In their view, the gender system should be understood as a dynamic structure, a designation of a network of processes, phenomena, ideas and expectations. The ordering of people by gender has also become the basis for other social, economic and political arrangements in society. The development of nontraditional practices in recent years has contributed to changing the meaning of male and female and thus changing the gender order, the social structures that in their turn shape gender practices. It has also contributed to the development of new identity categories and labels for them (Eckert \& McConnell-Ginet 2013:34). The researchers have proposed that there exists an implicit gender contract that must be negotiated as to how women and men relate to each other and which order will prevail: "Because structure and practice are in this dynamic and dialectical relation, there is always the possibility for change. One could say that the social order is in continual change [...] Life and daily living are about change - about things happening, about creativity and intelligence at work in the space left open by the incomplete hold of ideologies and institutions" (Eckert \& McConnell-Ginet 2013:34).

\section{Analysis of the texts}

The analysis will start by giving some extracts from the suspected persons' verbal narrative about the criminal offence from the interviews and what that reveals about the texts' social and discursive practices in the society, views on gender, ethics, religion and the legal system.

First we will show two extracts from trials from the nineteenth century, which were actually significant for cross-examination of the suspects (Drugge \& Lindgren 2001:39-40). The first example is from the case about Anders and Brita Stina, extract (1). During trial in 1836 Anders is confronted with all the evidence of the crime. The court operates under the Act from 1734. The judicial officials moralize over his offence, and he is asked if he repents and whether he understands what he has done and what the legal consequences are. Criminal Code 24, $\S 9$ in the Act of 1734 says: "if someone strikes another with a stone, rod, log, club, stick, hand or something else, so that he dies of it, or takes another man by the neck or scarf, so that he is strangled: may life be given for life." [Sw. "Slår man annan med sten, stång, trä, stör, käpp, hand eller annat, så at han dör theraf; eller tager man annan i hals eller halsduk, at han strypes; gifwe lif för lif.").

The protocol states: "Anders Persson, who assured that his statement would be truthful in all parts, could not provide any information about, or did not know how Brita Stina Andersdr had incurred the wounds in her face and skull that the autopsy protocol attested" ("att Anders Persson, som försäkrade att hans ofvanberörde upgifter till alla delar wore med sanning öfverensstämmande, icke kunde lemna någon upplysning om, eller kände huru och på hvad sätt 
Brita Stina Andersdr bekommit de åkommor i ansigtet och på hufvudskålen som Obductions Protocollet uptager"). Further on the protocol says:

(1) Anders Persson was confronted with the absurdity of his claim that he did not know how Brita Stina had sustained the injuries that were visible on her dead body. Anders declared, with obvious indifference, that his wife had gone out of the house for a short time, and when she returned had fallen down on the floor, probably because she was drunk, and thus inflicted the wounds on herself, and as Anders continued with this pretence, although the prosecutor tried to get Anders to remember that, immediately following the terrible event, he had voluntarily admitted to several people that he had beaten, kicked and rolled Brita Stina and that he had caused her death. The prosecutor requested [14 named witnesses] to be questioned, all of whom were now present, and because they were not disqualified, they spoke under oath.

Anders Persson föreställd orimligheten af sin upgift att icke känna hvarifrån Brita Stina Andersdr bekommit de svårare åkommor som på hennes döda kropp warit synliga, förklarade, under uppenbar liknöjdhet, att hustrun dels då hon på en kort stund aflägsnat sig från stugan, och dels då hon wid åter komsten omkullfallit på golfvet, troligen i fyllan och villan sjelf tillfogat sig desamma, och som Anders Persson uti ett slikt föregifvande fortfor, oaktadt Åklren sökte föra Anders Persson till minnes, att han genast efter den rysliga händelsen för flera tillstädes komne personer otvunget medgifvit att han slagit, sparkat och rullat Brita Stina Andersdr; och wore hennes bane man. Anhöll Åklren att såsom vittnen få afhörde [14 vittnen], hvilka samtlige nu woro tillstädes, och som Jäf emot dem icke förekom, fingo de aflägga wittneseden.

In extract (1) above, the words of the scribe "confronted with the absurdity" and "declared with indifference" show that the officials in the court were morally outraged by Anders Persson's impudence in court and lack of remorse, failing to confess what he did, even though witnesses had said under oath that he had obviously killed his wife. A consequence of his behaviour was that he was sentenced to be beheaded. The verdict was tested on 20 July 1836 by the Court of Appeal and finally by the Supreme Court on 26 October the same year. These instances confirmed the death penalty for Anders Persson, and he was beheaded on 3 February 1837.

The law that was applied when he was convicted was grounded in deontological ethics, which means that one's attitude towards fellow human beings is crucial, with the Old Testament's view of the law and how it should be implemented as a role model. This meant that if an act is performed out of a desire to do good it is always right, even if the consequences are disastrous. The point is to do what feels morally right.

The second example is from the cross-examination with the suspect Lars Erik Larsson from 1851; he was accused of murdering his wife Johanna:

(2) After the report was read out aloud, Lars Erik was asked about the cause of the several minor injuries that the autopsy had found on his wife's body. He said he could not say otherwise than that the injuries might have come from a bottle that Lars Erik had broken on the floor of the house or had been caused during the struggle when he had dragged her to the cellar, where she perhaps could have hit against doors and walls as well as casks and other things in the cellar; Lars Erik explained that he had not been drunk during the violent scene and had not had any intention to kill his wife.

Efter upläsandet hwaraf, Lars Erik Larsson, tillfrågad om orsaken till de flera mindre åkommor, hwilka wid obductionen befunnits å hustruns kropp, förmälde sig icke kunna derföre annorlunda redogöra, än att desamma möjligen dels tillkommit af på golfwet i stugan efter en af 
Lars Erik Larsson sönderslagen boutelj, och dels orsakats under handgemänget wid hennes utförande till källaren, hwarwid hon till äfwentyrs slagit och stött sig mot dörrar ochwäggar samt i källaren befintlige laggkärl och andre saker; förklarade Lars Erik Larsson, att han wid wåldsupträdet icke warit ankommen af starka drycker och icke derwid haft upsåt att hustrun afdagataga.

From the wording of extract (2), we see that Lars Erik says that he assured the court that he had no intention to kill his wife and that he had not been drunk during the violent scene, even though Lars Erik is vague about how the victim got the injuries. Lars Erik Larsson was sentenced to death but later pardoned, probably because he said he did not kill his wife intentionally and he was not drunk when it happened. The verdict of this case shows that, like the case discussed above, it too was grounded in deontological ethics and the ethics of the Bible, and therefore spared the life of Lars Erik because he said that he did not kill Johanna intentionally and his behaviour in court was considered appropriate as he acted and spoke as a Christian should do in the courtroom.

The first extract (3) from contemporary interviews is with a suspect from the twenty-first century. It is Enoch who is suspected of gross violation of a woman's integrity. He is accused of having attacked Erna, whom he lives with:

(3) Enoch was informed that Elisabeth claimed that she saw that Enoch pushed Erna so that she fell on the stove. Enoch says that "it is obvious that they stick together" [...] Erna also says that she was struck in the chest by him. He answers that he has never done that. He also says that he would never hit any woman, men should not do things like that. [...] Asked if he hit her in the chest Enoch said that he does not remember, but he thinks that he did not, and goes on to say that Erna at one time was with a neighbour partying. The neighbour beat Erna, it was about a month and a half ago.

Enok informerades om att Elisabeth sagt att hon sett att Enok knuffade Erna så att hon föll in i spisen. Enok säger att "det är klart att de håller ihop" [...] Erna säger också att hon ska ha blivit slagen i bröstet av honom. På det svarar Enok att det har han aldrig gjort. Han säger också att han aldrig slagit någon kvinna, det gör man inte som man. [...] På frågan om han slagit henne i bröstet vid samma tillfälle berättar Enok att det minns han inte, det tror han inte att han har gjort. Enok berättar att Erna vid något tillfälle varit inne hos grannen och festat. Grannen skall då ha slagit Erna. Enok uppskattar att det var för ca en och en halv månad sedan.

During the interview, Enoch is informed of the accusations against him, that he pushed Erna so that she fell and hurt herself. Enoch denies pushing her. Erna has also said that he struck her in the chest. He answers that he has never done that, and says that "men should not do things like that", which indicates that he would never hit a woman. The police go through all the charges and ask him if he hit her in the chest. Enoch said he does not remember, but he thinks he did not, and goes on to say that Erna was once partying with a neighbour who had beaten her.

From this document, we can see that Enoch denies every accusation, and he tries to divert attention by talking about the neighbour, claiming that he had beaten Erna. He often answers the police officer's questions by saying that he does not remember, which might be correct, since he was drunk when the crime was committed, but might also be a strategy to avoid responsibility. Enoch's verbal strategy is to deny, diminish his violent acts against Erna, and to project by putting the blame on somebody else, in this case the neighbour, or Enoch says that he does not remember. 
The second contemporary example (4) is from an interview with Besin, 24 years old, who, like Enoch, is suspected of gross violation of a woman's integrity against Bahiri, his girlfriend:

(4) Besin denied the offence. He stated that he had never been violent towards Bahiri, but he had only been verbally rude to her the times they quarrelled. [...] Besin stated that he has never beaten, kicked, threatened or given Bahiri hard shoves or "tackles" [...] Besin stated that he has never slapped Bahiri. [...] They [...] have just arrived home from a 15-day holiday trip. They have a good time together and have even talked about getting engaged. Besin also wants to add that he felt very bad when he was arrested. He got almost no food and therefore had trouble with his stomach for a week. He was very offended and wonders how he can get compensation for the suffering during the arrest.

Besin förnekade brott. Han uppgav att han aldrig hade varit våldsam mot Bahiri utan att han endast hade varit verbalt otrevlig mot henne de gånger de bråkade. [...] Besin uppgav att han aldrig har slagit, sparkat, hotat eller gett Bahiri hårdare knuffar eller "tacklingar" någonsin. [...] Besin uppgav att han aldrig har gett Bahiri några örfilar. [...] De [...] har precis kommit hem från en semester resa på 15 dagar. De har det bra tillsammans och har till och med pratat om förlovning. Besin vill också lägga till att han när han satt anhållen mådde mycket dåligt. Han fick nästan ingen mat utan hade besvär med magen en vecka efter detta. Han har under denna tiden upplevt sig mycket kränkt och undrar hur han kan få ersättning för det lidandet.

As we can see from the extracts, Besin denied the offence. He says that he has never been physically violent towards Bahiri and denies that he has ever mistreated her or been violent as he is accused of. But he admits that he has been verbally rude to her. Instead he claims that they had just arrived home from a holiday trip and that they had a good time together and had even talked about getting engaged. Besin also adds that he felt very bad when he was arrested and wonders how he can get compensation for the suffering during the detention. Besin's verbal strategy is to deny and diminish the accusations of his violent actions and to glorify the relationship between him and his girlfriend.

\section{Results - a comparison between the old and the modern texts}

A comparison between the texts shows that the contemporary texts seem to be put together like a patchwork quilt, and the reader gets no clear picture of what has happened; the text is probably difficult to grasp for any reader (cf. Byrman 2014). The interviews with statements from the parties in the case and the witnesses simply do not give a comprehensible structure. In comparison, the structure of the old texts written during trial is clear and easy to follow. One explanation for the clear structure might be that these old texts were probably edited before being printed.

From the personal data on the suspect we can conclude that the men in the old texts, suspects in trials for murder or manslaughter, are wealthy farmers in rural settings, often familiar with participating in decision-making bodies in the local community; they normally have high literacy and full legal capacity in society (cf. Gumble 2000). In contemporary trials of assault or gross violation of a woman's integrity the suspects are often unemployed workers in urban settings, not functionally literate and with weak legal capacity.

Concerning the nature of the crime, murder versus gross violation of a woman's integrity, it is doubtful whether the contemporary cases were regarded as crimes in accordance with the 
rule of law in the nineteenth century, since it was every man's duty to maintain order and discipline in his house, even by using some violence if necessary (cf. Pleijel 1970; Dolan (1994:91-92). Thus as long as he was allowed to use violence that was probably both accepted in the community and legally required, it gave relatives and neighbours no grounds to restrain him. It depended on how much violence he used when he kept order in his house. From a modern perspective, we may suppose that, if this systematic violence over a longer period had been reported in terms described as gross, perhaps these cases could have saved the lives of both victims and perpetrators, and the case would not have ended up in murder trials. The society and the laws have changed, and religion and ethics in the sacred traditional form are not as important now as in the old times. Today it is insignificant and more or less a non-issue, as the interviews record parties and witnesses in a neutral way with no moralization over the conduct of the suspects. In both the old and the contemporary texts the crime committed in these cases falls under public prosecution. In the nineteenth century religion and ethics were highly significant as trials in general are marked by an "ethics of mentality" based on assumptions of intent by the accused to commit a crime. Crimes like murder or manslaughter fell under public prosecution, but not gross violation of a woman's integrity or non-fatal assaults within marriage. As recently as in 1974 the Swedish law was changed, and domestic violence came under public prosecution. Thus, domestic violence in Sweden was considered a private affair until 1974. Eva Österberg has pointed out that there was no explicit discourse at all in Sweden concerning crime victimization in this sphere before the 1970s (Österberg 2002:294).

Even though much has changed, the results also show some similarities in the contemporary and the old texts. For example, all these cases are problematic for society to handle, both past and present, and not many contemporary cases reported to the police lead to prosecutions and convictions, as these crimes are difficult to prove in court, since the crime was often committed in privacy. The suspect's strategies for disclaiming accountability are the same: they diminish, deny and project their criminal actions. Crucial factors that lead to these crimes were described in the texts as either mental instability in both parties, abuse of drugs and power, mainly among men, lack of accountability and responsibility in the relationship or not seldom also as loss of honour, mainly for the men.

In the old texts the sheriffs and the legal officials try to get the suspect to admit his criminal conduct. In the modern texts the investigators retell the suspect's words in a neutral way with no obvious progression in the text, for example that the suspect's narrative will end up with a confession or conclusion. This way of writing the texts may have consequences for the possibility of taking the case to court, since the content of the text is difficult to understand, even for a prosecutor who is used to reading texts like this. In both old and new investigations the offender practises the rhetoric of disclaiming accountability towards the victim by a mitigating description of his violent actions (Hydén 1995a:133-152).

The ethics have changed: in the old text a deontological ethics is applied and explicit in the trials and texts, which means that rules and moral duty are central, deriving the rightness or wrongness of one's conduct from the character of the behaviour itself rather than the outcome of the conduct. Deontological ethics go back to the Old Testament tradition - an eye for an eye (Hauerwas 1985:11, 18-19; Drugge 2009). Unlike this old ethics, legal proceedings today apply a consequential ethics, which means that the consequences of one's conduct are 
the ultimate basis for any judgement about the rightness or wrongness of that conduct. These consequential ethics are implicit in the investigation and the trial.

\section{Gender relations over 150 years - a conclusion}

We can conclude that some significant changes have happened in society: the social structure, the interview techniques of the investigators, court proceedings, the application of the law in public prosecution, and in the enforcement of religion and ethics in legal matters.

We began by asking: How does the suspect speak about the crime he is suspected of, and how can his words be understood in a gender perspective? The men in the cross-examinations and interviews try to deny accountability for the crime and project their criminal behavior on others, especially on the woman in their relationship.

In a gender perspective this question could be explained through Eckert \& McConnellGinet's gender theory and Mattsson's comprehension of the theory. It seems that both the dichotomy and the hierarchy were easier to notice in nineteenth-century civil society. At that time the master of the house had the right to exercise domestic chastisement against wife, children and servants, at least to a certain extent. When the man ended up in court accused of murder, the situation changed. He was then considered a perpetrator of violence and a murderer and would be tried in court and punished. Sweden acquired a new Criminal Code in 1864, when it was no longer legal for a man to beat his wife (cf. Lindstedt Cronberg 2005:25; Eriksson 2005:49; Eriksson 2010:65-77, 85-97). However, very few women took the step to report the violence they were subjected to, as cases of domestic violence were subject only to private actions but not open for public prosecutions. Furthermore, as long as the man fulfilled his duties as breadwinner, he was probably not reported, but neglecting his duty as a husband or having severe mental illness might change that. There were clear ideas about how a woman should behave. If the woman did not look after her household duties, or was moody and impudent, the violence she was subjected to could appear legitimate, even though it was not legal after 1864 (cf. Eriksson 2010:221-236).

The growing gender conflict in society as a consequence of the modern age, where the expansive economy and democracy create the conditions for admitting women into a society built by men for men, inevitably leads to a gender crisis, typical for all modern western societies, because there must be negotiations as to how women and men relate to each other and which order will prevail. Anyway, the crisis must be resolved and many different solutions are possible (cf. Hearn \& Pringle 2009:1-19).

The results of this study indicate that the traditional hierarchy between women and men in the older texts could be altered when the man was weakened by ending up on trial. Although women and men are more equal in legal matters and in society at large than 150 years ago, the dichotomy and the hierarchy in contemporary texts still prevail and there is not yet full equality, although the gender contract has been renegotiated in different ways over the years due to changes in law and society.

How could the violence be understood? We can interpret the results from this study in the light of Mattsson's framework on domestic violence, which highlights how the tension of violence, power and gender makes it difficult to expose violence and women's vulnerability. Mattsson points out that there is a difference between perspectives that are based on struc- 
tural and relational understanding of the violence. The structural perspective gives prominence to the gender dimension of violence as a structural expression of male superiority and female subordination. The relational understanding places less emphasis on power relations and more on violence as the result of conflict between the two parties, and Hydén adopts a feminist perspective which she combines with a social psychological understanding, which emphasises the root of the violence - the quarrel. We can conclude that there is a tendency to similar explanations for the violence generated in the studied cases, both old and modern.

Jeff Hearn et al. 2016 state "that violence against women denotes violence that is directed towards women because they are women [...]; it is a clearly gendered category; it is not degendered. This framing recognizes the structural element of violence; violence is shaped by and structures social positions and gender orders, and serves to maintain inequality" (2016:2). This is a troublesome assertion, and regrettably it seems to also apply to the relations between the women and men in our study.

Today most cases of domestic violence are dropped and never go to trial in Sweden, which is a problem for the legal security of the citizens and for communities in general governed by law. The tendency that a majority of cases of domestic violence are dismissed (cf. Brottsförebyggande rådet 2014:9-10) is an embarrassing fact, since Sweden has a reputation for being a society with equal opportunities. The low rate of prosecution makes it a gender issue that should be addressed. How the gender relations in this discourse will be negotiated in the future, and how the Swedish legal system will deal with cases of domestic violence, remains open.

\section{References}

Anners, Erik. 1983. Den europeiska rättens historia: Några huvudlinjer. Stockholm: Norstedts.

Brottsförebyggande rådet, Brå. 2009. Våld mot kvinnor och män i nära relationer: Våldets karaktär och offrens erfarenheter av kontakter med rättsväsendet. Rapport 2009:12. Stockholm: Fritzes.

Brottsförebyggande rådet, Brå. 2014. Brott i nära relationer: En nationell kartläggning. Rapport 2014:8. Stockholm: Fritzes.

Byrman, Gunilla. 2014. Police Writing Techniques in Reported Interviews, book chapter 15, section III. The Evolution of Policing: Worldwide Innovations and Insights, New York. Taylor \& Francis Group, pp. 247-262.

Carlsson, Sten. 1994. Befolkningsutvecklingen från 1800-talets mitt. In Den svenska historien. 13 Emigrationen och det industriella genombrottet. Stockholm: Bonniers, pp. 26-30.

Coulthard, Malcolm. 1996. The official version: Audience manipulation in police records of interviews with suspects. In C.R. Caldas-Coulthard \& M. Coulthard (Eds.), Texts and Practices: Readings in Critical Discourse Analysis. London: Routledge, pp. 166-178.

Delling, Hannes. 2014. Ny kritik väntas mot häktestider. Dagens Nyheter 15 October 2014 [accessed 8 April 2016: http://www.svd.se/ny-fn-kritik-vantas-mot-haktestider lom/sverige].

Dolan, Frances E. 1994. Dangerous Familiars: Representations of Domestic Crime in England, 1550-1700. Ithaca: Cornell University Press.

Drugge, Ulf \& Lindgren, Simon. 2001. Med dödlig utgång: om grova våldsbrott och sociala former i 1800-talets Sverige. Umeå: Sociologiska inst., Umeå University. 
Drugge, Ulf. 2009. Crime and Psychiatry in Problematic Coexistence: Four Domestic Homicides and the Nineteenth-Century Courts. Journal of Scandinavian Studies in Criminology and Crime Prevention, Vol. 10, pp. 55-74.

Eckert, Penelope \& McConnell-Ginet, Sally. 2013. Language and Gender. 2nd ed. Cambridge: Cambridge University Press.

Eriksson, Marie. 2005. Fly, fäkta, förlikas eller förbliva i mannens våld? In Eva Österberg \& Marie Lindstedt Cronberg (Eds.), Kvinnor och våld: En mångtydig kulturhistoria. Lund: Nordic Academic Press, pp. 49-70.

Eriksson, Marie. 2010. Makar emellan: Äktenskaplig oenighet och våld på kyrkliga och politiska arenor, 1810-1880. Växjö: Linnaeus University Press.

Fairclough, Norman. 2010. Critical Discourse Analysis: The Critical Study of Language. Harlow: Longman.

Ferguson, Eliza Earle. 2010. Gender and Justice: Violence, Intimacy, and Community in Finde-Siècle Paris. Baltimore: The Johns Hopkins Press.

Gumbel, Ingatora. 2000. Hörd angående misshandel: Polisens protokoll vid förhör med misshandlade kvinnor och misstänkta män. Stockholm: Stockholms universitet, Institutionen för nordiska språk.

Hauerwas, Stanley. 1985. Character and the Christian Life: A Study in Theological Ethics. San Antonio: Trinity University Press.

Haworth, Kate. 2010. Police interviews in the judicial process: Police interviews as evidence. In M. Coulthard \& A. Johnson (Eds.), The Routledge Handbook of Forensic Linguistics. New York, N.Y.: Routledge, pp. 169-181.

Hearn, Jeff \& Pringle, Keith. 2009. Studying Men in Europe. In Jeff Hearn \& Keith Pringle (Eds.), European Perspectives on Men and Masculinities: National and Transnational Approaches. Houndmill, Basingstoke: Palgrave Macmillan, pp. 1-19.

Hearn, Jeff, Sofia Strid, Liisa Husu \& Mieke Verloo. 2016. "Interrogating violence against women and state violence policy: Gendered intersectionalities and the quality of policy in The Netherlands, Sweden and the UK". Current Sociology vol. 64, no. 4, pp. 551567. [Retrieved 5 January 2017: http://journals.sagepub.com/doi/pdf/10.1177/0011 392116639220].

Hydén, Margareta. 1995a. Kvinnomisshandel inom äktenskapet: Mellan det omöjliga och det möjliga. Stockholm: Liber utbildning.

Hydén, Margareta. 1995b. "Mot en förståelse av kvinnomisshandel som en social process". Kvinnovetenskaplig tidskrift, vol. 16, pp. 67-74.

Inger, Göran. 1997. Svensk rättshistoria. Stockholm: Liber ekonomi.

Komter, Marta. 2002. The suspect's own words: The treatment of written statements in Dutch court-rooms. In Forensic Linguistics 9(2), pp. 168-192.

Komter, Marta. 2006. From talk to text: The interactional construction of a police record. In Research on Language and Social Interaction 39/3, pp. 201-228.

Komter, Martha. 2013. Travels of a Suspect's Statement. In Heffer, Chris, Rock, Frances \& Conley, John M. (ed.) Legal-lay Communication: Textual Travels in the Law. Oxford University Press.

Lindstedt Cronberg, Marie. 2005. Mäns våld mot kvinnor i 1800-talets Sverige: Hustrumisshandel som manlig ritual. In Eva Österberg \& Marie Lindstedt Cronberg (Eds.), Kvinnor och våld: En mångtydig kulturhistoria. Lund: Nordic Academic Press, pp. 2348.

Lundgren, Eva, Gun Heimer, Jenny Westerstrand \& Anne-Marie Kalliokoski. 2001. Slagen dam: Mäns våld mot kvinnor i jämställda Sverige - en omfångsundersökning. Stockholm: Fritzes. 
Macfarlane, Alan. 2004. To Contrast and Compare. In Vinay Kumar Srivastava (ed.), Methodology and Fieldwork. Delhi: Oxford University Press.

Mattsson, Tina. 2013. Motstånd och neutralisering: Kön, makt och professionalitet i arbetet med våld i nära relationer. In Socialvetenskaplig tidskrift 20(3-4). pp. 150-167. [Retrieved 3 January 2017: http://journals.lub.lu.se/index.php/svt/article/viewFile/157 48/14231].

Österberg, Eva. 2002. Kvinnor och barn som offer: Diskurs och praxis från reformation till modernitet. In Eva Bergenlöv, Marie Lindstedt Cronberg \& Eva Österberg (Eds.), Offer för brott: Våldtäkt, incest och barnamord $i$ Sveriges historia från reformationen till nutid. Lund: Nordic Academic Press, pp. 291-306.

Pleijel, Hilding. 1970. Hustavlans värld: Kyrkligt folkliv i äldre tiders Sverige. Stockholm: Verbum.

Rock, Frances. 2013. Every Link in the Chain: The police interview as textual intersection. In Legal-lay Communication: Textual Travels in the Law. Oxford University Press, pp. 73-103.

Statistisk årsbok 2014. Stockholm: SCB. 